ZOOLOGIA 27 (5): 757-760, October, 2010

doi: $10.1590 /$ S1984-46702010000500013

\title{
Habitat selection and maturation of Saccocoelioides nanii (Digenea: Haploporidae) in Prochilodus argenteus (Actinopterygii: Prochilodontidae) from the São Francisco River, Brazil
}

\author{
Cassandra M. Monteiro' $\&$ Marilia C. Brasil-Sato ${ }^{1,2}$ \\ 1 Departamento de Biologia Animal, Universidade Federal Rural do Rio de Janeiro. Rodovia BR 465, $\mathrm{km} 7$, \\ Caixa Postal 74539, 23851-970 Seropédica, RJ, Brazil. \\ 2 Corresponding author. E-mail: mcbsato@ufrri.br
}

\begin{abstract}
This work examined the possible preference of Saccocoelioides nanii Szidat, 1954 for the three major intestinal portions of Prochilodus argenteus Agassiz, 1829 and statistically evaluated whether the river water level dynamic interfered in the parasite's ecological parameters and in its transmission to the definitive host. One-hundred-fifty specimens of $P$. argenteus were collected in July, 2003 (dry season) and in January, 2004 (rainy season) in the upper São Francisco River, State of Minas Gerais, Brazil. Of the 150 hosts, 96 (64\%) were parasitized by S. nanii. The mean intensity and abundance were $32.6 \pm 34.8$ and $20.8 \pm 31.9$, respectively, and the range of infection intensity was from 1 to 177 . The abundance of $S$. nanii was higher in the middle intestine than in either the anterior or posterior portions. This selection could be evidence of niche restriction to facilitate mating. The proportion of non-pregnant specimens of $S$. nanii was higher in the dry season as well as the intensity and abundance. At least two hypotheses can be considered for elucidated this inference: the presence/absence or change in the quantity of some substance in the host body amending/inhibits the reproduction of the parasite or that non-pregnant specimens corresponds to newly recruited individuals who did not have time to reproduce.
\end{abstract}

KEY WORDS. Niche; parasite ecology, São Francisco Basin.

Species of Saccocoelioides Szidat, 1954 live in the intestine of freshwater and occasionally estuarine fish in North and South America (OverstreEt \& CURRAN 2005). KoHn (1985) presented new morphological data, measurements and figures of the syntypes of Saccocoelioides nanii Szidat, 1954. Dyer et al. (1999) described Saccocoelioides agnostomun Dyer, Bunkley-Williams \& Williams Jr, 1999 and provided a summary of the genus Saccocoelioides. Lizama et al. (2006) analyzed the influence of seasonal and environmental patterns and host reproduction on S. nanii and other metazoan parasites of Prochilodus lineatus (Valenciennes, 1836). They showed that the abundance of the latter was higher during the reproductive period of the host, and that the prevalence was positively correlated with water temperature. There is no available information on the distribution of $S$. nanii and the species' preference for a particular portion of the host's intestine. Other aspects of the biology of $S$. nanii are also unknown, such as life cycles and the correlation between host and parasite reproductive periods. Prochilodus argenteus Agassiz, 1829, known popularly as the "curimatá-pacú", is a detritivorous species (Аlvim \& Peret 2004) that migrates long distances (Gomes \& Verani 2003). It is endemic to the São Francisco River and makes up a considerable portion of the fish catch in the upper São Francisco region (SATо et al. 1996).
The rainy and dry seasons are well defined in the upper São Francisco basin. The beginning of the rainy season and the associated limnological changes trigger the start of reproduction of migratory spawning fish species (LowE-McConnell 1987).

In this paper, the possible preference of $S$. nanii for some portions of the intestine of $P$. argenteus is evaluated, as well as whether the river water level dynamics interferes in with the parasite's ecology, and thus with its transmission to the definitive host.

\section{MATERIAL AND METHODS}

One-hundred and fifty specimens of $P$. argenteus were collected in July, 2003 (dry season - 89 specimens) and in January, 2004 (rainy season - 61 specimens) in the region of the upper São Francisco River, downstream from the Três Marias Dam $\left(18^{\circ} 12^{\prime} 32^{\prime \prime} \mathrm{S}, 45^{\circ} 15^{\prime} 41^{\prime \prime} \mathrm{W}\right)$, in the municipality of Três Marias, State of Minas Gerais, Brazil. In the necropsies, the intestine was divided into three portions: anterior, middle and posterior. The specimens of Digenea found in the infected hosts were counted to compose the three infrapopulations based on each intestinal portion. Specimens were processed according to АмAто et al. (1991) to obtain permanent slides, and identified according to Travassos et al. (1969). 
The prevalence, intensity and abundance of $S$. nanii were calculated for all samples combined, and in separate, for the two rainfall periods (rainy and dry), and abundance was also calculated separately for the anterior (AI), middle (MI) and posterior intestinal (PI) portions. To determine whether the $S$. nanii parasites were more abundant at a particular portion of the intestine, the Friedman test $\left(\chi_{\mathrm{r}}^{2}\right)$ and the Mann-Whitney (U) test were used to detect possible pair-wise differences in abundance. In the statistical analyses, all hosts included were parasitized in at least one intestinal region. The helminths of hosts that showed abundance greater than or equal to the mean of each season were separated into two groups: not pregnant (without eggs in the uterus) and pregnant (with eggs in the uterus). The Chi-square $\left(\chi^{2}\right)$ test was used to compare the proportion of pregnant and non-pregnant specimens of $S$. nanii between the two periods (rainy and dry). The Chi-square test with Yates' correction was used to verify if the prevalence (P) was influenced by the rainfall dynamic of the São Francisco River, and the Mann-Whitney test to evaluate the variation in intensity (I) and abundance (A) of parasites. The ecological terminology follows Bush et al. (1997) and the statistical tests followed ZAR (1996), to the level of significance, $p<0.05$. Voucher specimens of the host were deposited in the Museu de Zoologia of the Universidade de São Paulo (USP), São Paulo, Brazil (MZUSP 95167), and specimens of S. nanii in the Coleção Helmintológica do Instituto Oswaldo Cruz, Rio de Janeiro, Brazil (CHIOC 36917, 36918a, b).

\section{RESULTS}

Of the 150 hosts examined, 96 (64\%) were parasitized by $S$. nanii. The prevalence, range, mean intensity and mean abundance of $S$. nanii are given for the total sample, and for the two rainfall periods (Tab. I). The abundance at the different intestinal portions (Tab. II), and the proportion of pregnant and non- pregnant individuals in each rainfall period (Tab. III) are also presented.

The intensity and abundance of the parasites were higher in the dry season ( $\mathrm{I}=41.21 \pm 38.42, \mathrm{~A}=30.56 \pm 37.68)$ than in the rainy season $(\mathrm{I}=13.50 \pm 10.97, \mathrm{~A}=6.64 \pm 10.22)(\mathrm{U}=425.50$, $\mathrm{p}<0.0001$ and $\mathrm{U}=1472.00, \mathrm{p}<0.0001$, respectively). There was no significant difference in the prevalence of $S$. nanii between the two sampling periods $\left(\chi^{2}=8.74, \mathrm{p}=1.508\right)$.

Thirteen hosts had only parasites at one portion of the intestine: one in the anterior intestine (7.69\%), ten in the middle intestine (76.92\%) and two in the posterior intestine (15.38\%). The abundance of $S$. nanii was higher in the middle intestine (A $=11.17 \pm 20.77)$ than in the anterior $(\mathrm{A}=5.23 \pm 9.88)$ or posterior $(\mathrm{A}=4.43 \pm 0.10)$ of $P$. argenteus $\left(\chi_{\mathrm{r}}^{2}=23.93, \mathrm{p}<0.0001\right)(\mathrm{AI}-$ MI: $\mathrm{U}=-3.96, \mathrm{p}<0.0001 ; \mathrm{AI}-\mathrm{PI}: \mathrm{U}=-1.11, \mathrm{p}=0.266$; MI - PI: $\mathrm{U}$ $=-4.84, \mathrm{p}<0.001)$, respectively. The proportion of non-pregnant specimens of $S$. nanii in the samples was higher in the dry season $\left(\chi^{2}=18.01, \mathrm{p}<0.0001\right)$.

\section{DISCUSSION}

In general, helminths are highly specific (Sтоск \& HoLmes 1988), and are characterized by having habitat preferences within specific host sites. Each parasite occupies its own habitat, since the resources are limited in the host (SuKHDEO 1990). This study has shown that the middle intestine of $P$. argenteus is the region most commonly used by $S$. nanii. This preference could be a result of a niche restriction that facilitates mating (RoHDE 1994). The anterior and posterior portions of the intestine were rarely infected by other adult helminths, and may be considered underexploited, thus constituting vacant niches available for colonization by $S$. nanii. Although the middle intestine was region most heavily parasitized by $S$. nanii, the distribution of individuals of this species along the entire intestine may represent a low level of specialization of this host

Table I. Prevalence, range, mean intensity, mean abundance of S. nanii of $P$. argenteus, from the São Francisco River, Três Marias, Minas Gerais, Brazil.

\begin{tabular}{lcccc}
\hline \multicolumn{1}{c}{ Seasons } & Prevalence (\%) & Range & Mean intensity & Mean abundance \\
\hline Rainy season & 49.18 & $1-50$ & $13.50 \pm 10.97$ & $6.64 \pm 10.22$ \\
Dry season & 74.15 & $1-177$ & $41.21 \pm 38.42$ & $30.56 \pm 37.68$ \\
\hline Total & 64.00 & $1-177$ & $32.55 \pm 34.84$ & $20.83 \pm 31.93$ \\
\hline
\end{tabular}

Table II. Abundance of $S$. nanii in the different intestinal portions of $P$. argenteus, from the São Francisco River, Três Marias, Minas Gerais, Brazil.

\begin{tabular}{cr}
\hline Intestinal portion & Abundance \\
\hline Anterior & $5.23 \pm 9.88$ \\
Middle & $11.17 \pm 20.77$ \\
Posterior & $4.43 \pm 0.10$ \\
\hline
\end{tabular}

Table III. Proportion of pregnant and non-pregnant specimens of $S$. nanii of $P$. argenteus, from the São Francisco River, Três Marias, Minas Gerais, Brazil, in the rainfall periods.

\begin{tabular}{ccc}
\hline Rainfall periods & Pregnant (\%) & Non-pregnant (\%) \\
\hline Dry & 27.30 & 72.70 \\
Rainy & 41.55 & 58.45 \\
\hline
\end{tabular}


regarding infection site, directly related to its high tolerance to the physiological conditions in each portion of the intestine (STоск \& Holmes 1988). It is possible that the absence of other helminths allows $S$. nanii to expand its distribution to other areas with available resources to accommodate a greater number of parasites through occupation of a broader range of niches. The latter would be difficult in the presence of competitors (Poulin 2007).

LizAma et al. (2006) showed that the abundance of $S$. nanii in $P$. lineatus was higher during the rainy season the same is valid during the dry season for $S$. nanii in P. argenteus. Abiotic factors can interfere directly and/or indirectly in the development of parasites (Poulin 1996). Changes in water temperature, for example, can have a direct influence on the free-living larval stages of parasites, and can indirectly affect their growth, maturation, and reproduction inside their hosts (POJMÁNSKA 1995). Alterations in the physical-chemical parameters of the water at the beginning of the rainy season trigger the start of the spawning season of $P$. argenteus, which occurs from November to January (SATO et al. 2003). The presence of non-pregnant individuals in both dry and rainy seasons suggests that the biological cycle of $S$. nanii was maintained in the two periods and that it was not synchronized with that of the host. Similarly, there were digenetic specimens with the uterus filled with eggs in both seasons. These results indicate a discrete seasonal maturation pattern for $S$. nanii. However, the proportion of non-pregnant digenetics in the infrapopulations was higher in the dry season, probably due to an increase in larval recruitment by the definitive host in this period. The presence of pregnant specimens of $S$. nanii in the two periods indicates that there is no synchronization between the reproduction of the parasite and the host. It also demonstrates that the intermediate and definitive hosts of $S$. nanii share the same environment both in the rainy and dry seasons, thus permitting the continuity of the parasite's biological cycle. The abundance of $S$. nanii in the dry season was a reflection of the greater number of non-pregnant specimens at infrapopulation, since the number of adults did not change significantly. From this observation, two hypotheses can be generated: 1) non-pregnant specimens may be a result of physiological changes in the host, which may have impacted the reproduction of the parasite. Hosts have mechanisms to maintain their homeostasis, i.e. their physical and chemical parameters within specified levels (СомвEs 2001). Changes in hormones and other substances related to sexual maturation and reproduction, however, may impact the egg production in S. nanii; 2) non-pregnant specimens can be considered newly recruited individuals who have not had enough time to mature. Studies on the life cycle of species of Saccocoelioides address only the developmental stages that occur in the aquatic environment and in the invertebrate host (see Martorelli 1988, Díaz \& GonZÁlez 1990). Therefore, there is no information available about the time needed for sexual maturation and early reproduction in the definitive host. However,
Díaz et al. (2009) elucidated the life cycle of Culuwiya tilapiae (Nazir \& Marval, 1976) in Venezuela, and compared it to that of other living species Culuwiya Overstreet \& Curran, 2005 and Saccocoelioides tarpesensis Díaz \& González, 1990 (Haploporidae). They considered the life-cycle of all these species to be similar, at least in the early stages of development. Culuwiya tilapiae needs approximately 23 days inside the host to start reproduction (Díaz et al. 2009). If the cycle of $S$. nanii follows a similar pattern to that of other species in the family, non-pregnant specimens found in the gut of $P$. argenteus can correspond to newcomers who have not yet started eggs production.

\section{ACKNOWLEDGMENTS}

We thank Ivan B.M. Sampaio of the Veterinary School of Universidade Federal de Minas Gerais for delineating the statistical analyses of the data; to Yoshimi Sato, Estação de Hidrobiologia e Piscicultura of CODEVASF for the resources, to CEMIG/CODEVASF working arrangement, to UFRRJ/IBAMA (MG) technical-scientific agreement co-operation for providing logistical and material support; to Philip J. Scholl for English revision, and the Capes for a postgraduate scholarship grant to the first author.

\section{LITERATURE CITED}

Alvim, M.C.C. \& A.C. Peret. 2004. Food resources sustaining the fish fauna in a section of the upper São Francisco river in Três Marias, MG, Brazil. Brazilian Journal of Biology 64 (2): 195-202.

Amato, J.F.A.; W.A. Boeger \& S.B. Amato. 1991. Protocolos para Laboratório: Coleta e Processamento de Parasitos de Pescado. Seropédica, Gráfica da Universidade Federal Rural do Rio de Janeiro, 81p.

Bush, A.O.; K.D. Lafferty; J.M. Lotz \& A.W. Shostak. 1997. Parasitology meets Ecology on its own terms: Margolis et al., revisited. Journal of Parasitology 83 (4): 575-583.

Combes, C. 2001. Parasitism: The ecology and Evolution of Intimate Interactions. Chicago, The University of Chicago Press,728p.

Díaz, M.T. \& T.G. González. 1990. Ciclo de vida de Saccocoelioides tarpazensis n. sp. (Trematoda: Haploporidae). Acta Científica Venezolana 41: 327-336.

Díaz, M.T.; A.K. Bashirullah; L.E. Hernández \& E. Gómez. 2009. Life cycle of Culuwiya tilapiae (Nasir y Gómez, 1976) (Trematoda: Haploporidae) in Venezuela. Revista Científica de América Latina 19 (5): 439-445.

Dyer, W.G.; L. Bunkley-Williams \& E.H. Williams JR. 1999. Saccocoelioides agonostomus sp. nov. (Digenea: Haploporidae) from the Mountain Mullet and the Serajo Goby in Puerto Rico, with a Summary of the Genus. Caribbean Journal of Science 35 (3-4): 225-230.

Gomes, J.H.C. \& J.R. Verani. 2003. Alimentação de espécies de peixes do reservatório de Três Marias, p. 195-228. In: 
Godinho, H.P. \& A.L. Godinho (Eds). Águas, peixes e pescadores do São Francisco das Minas Gerais. Belo Horizonte, PUC Minas, 468p.

КонN, A. 1985. On the species described by Szidat in 1954 in the genus Saccocoelioides (Digenea: Haploporidae). Memórias do Instituto Oswaldo Cruz 80 (4): 611-622.

Lizama, M.L.P.L.; R.M. TAKemoto \& G.C. Pavanelli. 2006. Influence of the seasonal and environmental patterns and host reproduction on the metazoan parasites of Prochilodus lineatus. Brazilian Archives of Biology and Technology 49 (4): 611-622.

Lowe-McConNeLL, R.H. 1987. Ecological studies in tropical fish communities. London, Cambridge University Press, 400p.

Martorelli, S.R. 1988. Estudios parasitológicos en biotopos lênticos de la República Argentina III. El ciclo biológico de Saccocoelioides carolae Lunaschi (Digenea) parásito de Cichlasoma facetum (Jenyns, 1842) (Pisces: Cichlidae). Neotrópica 32: 125-132.

Overstreet, R.M. \& C.C. Curran. 2005. Family Haploporidae Nicoll, 1914, p. 129-165. In: A. Jones; R.A. Bray \& D.I. Gibson (Eds). Keys to Trematoda. London, CAB International and The Natural History Museum, vol. 2, 745p.

POJMÁNSKA, T. 1995. Seasonal dynamics of occurrence and reproduction of some parasites in four cyprinid fish in ponds. III. Digenea, Cestoda, Crustacea and Hirudinea. Acta Parasitologica 40 (3): 142-147.

Submitted: 02.VI.2009; Accepted: 24.VI.2010. Editorial responsibility: Marcus V. Domingues
Poulin, R. 1996. The evolution of life history strategies in parasitic animals. Advances in Parasitology 37 (1): 107-134.

Poulin, R. 2007. Evolucionary Ecology of Parasites. Princeton, Princeton University Press, 332p.

RoHDE, K. 1994. Niche restriction in parasites: proximate and ultimate causes. Parasitology 109: 69-84.

Sato, Y.; E.L. Cardoso; A.L. Godinho \& H.P. Godinho. 1996. Hypophysation parameter of the fish Prochilodus marggravii obtained in routine hatchery station conditions. Brazilian Journal of Biology 56 (1): 56-59.

Sato, Y.; N. Bazzoli; E. Rizzo; M.B. Boschi \& M.O.T. Miranda. 2003. Impacto a jusante do reservatório de Três Marias sobre a reprodução do peixe reofílico curimatá-pacú (Prochilodus argenteus), p. 327-345. In: H.P. GodinHo \& A.L. GodinHo (Eds). Águas, peixes e pescadores do São Francisco das Minas Gerais. Belo Horizonte, PUC Minas, 468p.

Sтоск, T.M. \& J.C. Holmes. 1988. Functional relationships and microhabitat distributions of enteric helminths of grebes (Podicipedidae): the evidence for interactive communities. Journal of Parasitology 74 (2): 214-227.

SukHdeo, M.V. 1990. Habitat selection: a hypothesis. Parasitology Today 6 (7): 234-237.

Travassos, L.; J.F.T. de Freitas \& A. Kohn. 1969. Trematódeos do Brasil. Memórias do Instituto Oswaldo Cruz 67: 1-886.

ZAR, J.H. 1996. Biostatistical Analysis. New Jersey, Prentice Hall, $\mathrm{X}+918 \mathrm{p}$.

ZOOLOGIA 27 (5): 757-760, October, 2010 